\title{
Coexpression of Platelet-derived Growth Factor (PDGF) and PDGF-receptor Genes by Primary Human Astrocytomas May Contribute to their Development and Maintenance
}

\author{
Marius Maxwell," Stephen P. Naber," Hubert J. Wolfe," Theofanis Galanopoulos, * E. Tessa Hedley-Whyte, \$\|| \\ Peter McL. Black, "\# and Harry N. Antoniades*** \\ ${ }^{*}$ The Center for Blood Research $;^{\ddagger}$ the Division of Neurosurgery of Brigham and Women's Hospital; ${ }^{\S}$ the Department of Neuropathology, \\ Massachusetts General Hospital, Harvard Medical School; "Departments of Surgery and Pathology, Harvard Medical School; \\ "Department of Pathology, Tufts University-New England Medical Center; and **The Division of Biological Sciences, \\ Harvard School of Public Health, Boston, Massachusetts 02115
}

\begin{abstract}
The present studies investigated the expression of the two PDGF genes (c-sis/PDGF-2 and PDGF-1) and the PDGF-receptor $b$ gene (PDGF-R) in 34 primary human astrocytomas. Northern blot analysis demonstrated the coexpression of the c-sis/PDGF-2 protooncogene and the PDGF-R gene in all astrocytomas examined. The majority of the tumors also expressed the PDGF-1 gene. There was no correlation between the expression of the two PDGF genes. Nonmalignant human brain tissue expressed the PDGF-R and PDGF-1 genes but not the c-sis/PDGF-2 protooncogene. In situ hybridization of astrocytoma tissue localized the expression of the c-sis and PDGF-R mRNA's in tumor cells. Capillary endothelial cells also expressed c-sis mRNA. In contrast, nonmalignant human brain tissue expressed only PDGF-R mRNA but not c-sis/ PDGF-2 mRNA. The coexpression of a potent mitogenic growth factor protooncogene (c-sis) and its receptor gene in astrocytoma tumor cells suggests the presence of an autocrine mechanism that may contribute to the development and maintenance of astrocytomas. The expression of c-sis mRNA in tumor cells but not in nonmalignant brain cells may serve as an additional diagnostic criterion for the detection of astrocytomas in small tissue specimen using in situ hybridization for the detection of c-sis mRNA and/or immunostaining for the recognition of its protein product. (J. Clin. Invest. 1990. 85:131-140.) Key words: platelet-derived growth factor $\bullet$ c-sis protooncogene - PDGF-recept - PDGF and PDGF-receptor genes $\bullet$ autocrine function $\bullet$ in situ hybridization
\end{abstract}

\section{Introduction}

Astrocytomas are aggressive brain tumors that numerically exceed all other primary intracerebral neoplasms (1). The malignant progression of astrocytomas is associated with de-differentiation and the morphology of the most malignant form, glioblastoma multiforme, has been likened to their embryonic progenitor cells (2-5).

Address reprint requests to Dr. Antoniades, Center for Blood Research, 800 Huntington Avenue, Boston, MA 02115.

Received for publication 21 December 1989 and in revised form 9 March 1990.

J. Clin. Invest.

(c) The American Society for Clinical Investigation, Inc. $0021-9738 / 90 / 07 / 0131 / 10 \quad \$ 2.00$

Volume 86, July 1990, 131-140
The molecular events associated with the pathogenesis and maintenance of astrocytomas are unknown. Data linking the amplification and over-expression of certain protooncogenes encoding growth factors or their receptors with specific human tumors and patient survival time have been reported. For example, amplification of $\mathrm{N}-m y c$ in human neuroblastomas has been correlated with the pathologic stage of the tumor (6), and amplification of c-myc in advanced human lung cancer appears to be associated with shorter survival time (7). Recently, it has been claimed that amplification of the HER-2/neu gene correlates with a shorter time to relapse and lower survival rate in women with breast and ovarian cancers (8). Furthermore, amplification of HER-2/neu may identify a specific pathological subset of breast carcinomas (9). Amplification and enhanced expression of the epidermal growth factor receptor (EGF-R) gene in certain primary human brain tumors of glial origin has been suggested to represent a particular feature of these tumors (10). The presence of an amplified, highly expressed gene, called GLI, has been observed in a single human malignant glioma $(11,12)$.

An important finding is that cultured astrocytoma cells express the c-sis protooncogene $(13,14)$. This gene is homologous to the transforming gene of the simian sarcoma virus (SSV), ${ }^{1}$ which encodes the PDGF-2 chain of platelet-derived growth factor (15-18). PDGF is a potent mitogen for cultured cells of mesenchymal origin such as diploid fibroblasts, arterial smooth muscle cells and brain glial cells (19). It consists of two homologous polypeptide chains, one encoded by the c-sis/ PDGF-2 protooncogene localized in chromosome 22 , and the other (PDGF-1) encoded by a gene localized in chromosome 7 (20-23). Astrocytoma cells in culture also express the gene encoding the PDGF-1 (A) chain of PDGF in addition to the c-sis PDGF-2 oncogene $(14,22)$. Recent studies have demonstrated the expression of the two PDGF genes and the PDGF receptor (PDGF-R) gene in three primary human astrocytomas (24). Normal astrocytes in culture express cell-surface PDGF receptors and are targets for the potent mitogenic action of PDGF (25). However, these normal astrocytes do not express the PDGF genes. Therefore, the inappropriate expression of genes encoding PDGF and the coexpression of PDGF$R$ by astrocytes may represent important steps in the development, proliferation and maintenance of the malignant astrocyte. This possibility is strengthened by the finding that the

1. Abbreviations used in this paper: EGF-R, epidermal growth factor receptor; GFAP, glial fibrillary acidic protein; ISH, in situ hybridization; PDGF, platelet-derived growth factor; SSV, simian sarcoma virus. 
intracranial injection of SSV, carrying the v-sis oncogene which encodes the PDGF-2 chain, can induce a high frequency of gliomas in newborn marmosets (26).

The mitogenic action of PDGF is mediated through binding to specific cell surface PDGF-receptors. The receptor that binds human PDGF and the c-sis/PDGF-2 homodimer has been cloned from mouse and human fibroblasts $(27,28)$, and is currently referred to as the $b$ receptor $(29,30)$. This receptor does not recognize the PDGF-1 homodimer which binds to a separate $a$ receptor $(29,30)$. This $a$ receptor has been cloned recently from human cells and was shown to bind to all three PDGF isoforms (31). The PDGF-R cited in these studies refers to the $b$ receptor that has a specificity for the c-sis/PDGF-2 homodimer and the human PDGF heterodimer.

In this study we present data on the co-expression of the two PDGF genes and the PDGF-R gene in vivo, in 34 primary human astrocytomas. Gene expression was investigated by Northern blot analysis. Identification of the cells of origin expressing these genes was established by in situ hybridization and immunochemical techniques.

\section{Methods}

Tissue collection. For Northern blot analysis tissues were collected intraoperatively and were immediately snap frozen in liquid nitrogen before being stored in a $-80^{\circ} \mathrm{C}$ freezer. For in situ hybridization, tissue specimens were immersed in ice-cold $4 \%$ paraformaldehyde and processed as described below. Of the $\mathbf{3 4}$ tumors investigated in these studies, 27 were derived from patients with glioblastoma multiforme and 7

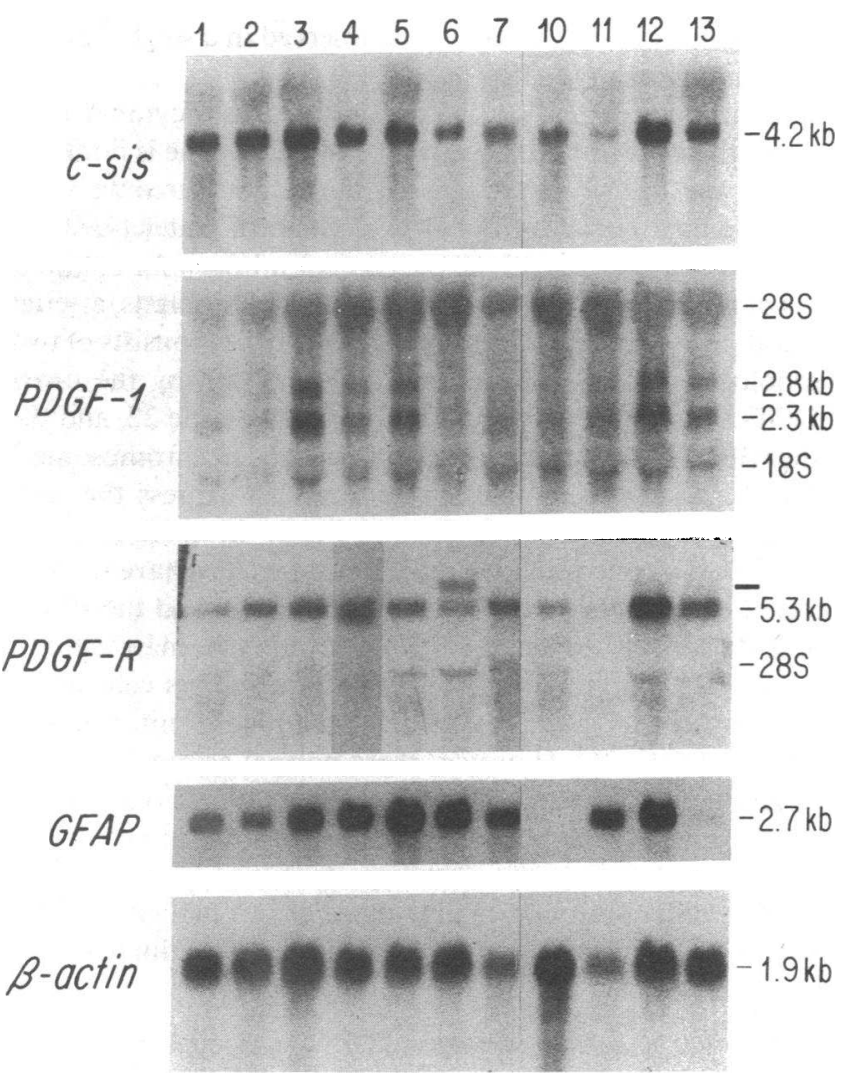

Figure 1. Northern blot analysis for c-sis/PDGF-2, PDGF-1, and PDGF-R(B) genes in primary human astrocytomas.

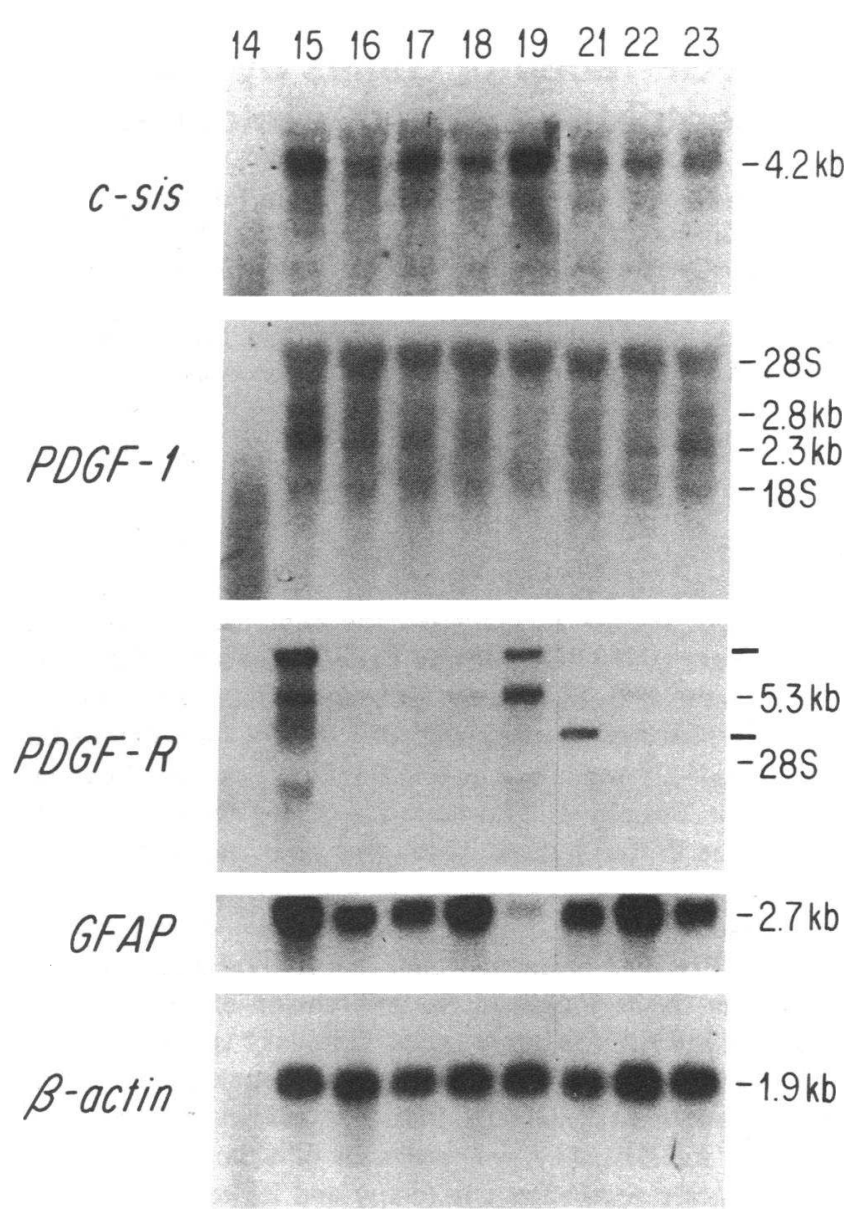

Figure 2. Northern blot analysis for c-sis/PDGF-2, PDGF-1, and PDGF-R(B) genes in primary human astrocytomas. Notice novel PDGF-R transcripts in lanes $15(3.2,5.3,7.2 \mathrm{~kb})$, lane $19(5.3,7.2$ $\mathrm{kb})$, lane $21(3.2 \mathrm{~kb})$.

were from patients with anaplastic astrocytomas (Table I). Nonmalignant human brain tissue was obtained from autopsies of two accidental deaths and intraoperatively from three patients with seizures.

Northern blot analysis. Fragments of tissue were immediately placed in ice-cold $4 \mathrm{M}$ guanidinium isothiocyanate (Fluka Chemicals, Buchs, Switzerland) before being homogenized by a Polytron (setting 6 for $45 \mathrm{~s}$ ). After being centrifuged for $2 \mathrm{~min}$ at $1,000 \mathrm{rpm}$, the supernatant fluid was carefully layered on a cesium chloride cushion and centrifuged (Beckman Instruments, Inc., Fullerton, CA) in an SW 50.1 rotor at $35,000 \mathrm{rpm}, 20^{\circ} \mathrm{C}$ for $18 \mathrm{~h}$. Total RNA was then extracted by standard ethanol precipitation after phenol extraction. Aliquots of RNA $(25 \mu \mathrm{g})$ were heated at $95^{\circ} \mathrm{C}$ for $2 \mathrm{~min}$ in a solution containing $50 \%$ formamide, $6 \%$ formaldehyde and running buffer $(20 \mathrm{mM}$ MOPS, pH 7.0, containing $5 \mathrm{mM}$ sodium acetate, $1 \mathrm{mM}$ EDTA). The samples were electrophoresed at $35 \mathrm{~V}$ overnight on $1 \%$ agarose gels containing $6 \%$ formaldehyde and running buffer.

The RNA was transferred to Nytran nylon membranes (Schleicher \& Schuell, Inc., Keene, NH), using $10 \times$ SSC transfer buffer, and baked at $80^{\circ} \mathrm{C}$ for $1 \mathrm{~h}$ in a vacuum oven. The membranes were then hybridized at $42^{\circ} \mathrm{C}$ for $16 \mathrm{~h}$ with $1 \times 10^{6} \mathrm{cpm} / \mathrm{ml}$ of random-primer labeled (Amersham Corp., Arlington Heights, IL) cDNA probe, in a solution containing $50 \%$ formamide (Kodak), $0.1 \%$ SDS, $5 \times$ SSPE, $5 \times$ Denhardt's mixture and $200 \mu \mathrm{g} / \mathrm{ml}$ salmon sperm DNA (Sigma Chemical Co., St. Louis, MO). After washing at $65^{\circ} \mathrm{C}$ with $0.1 \times \mathrm{SSC}, 1 \% \mathrm{SDS}$, the membranes were subjected to autoradiography at $-70^{\circ} \mathrm{C}$ using intensifier screens. 


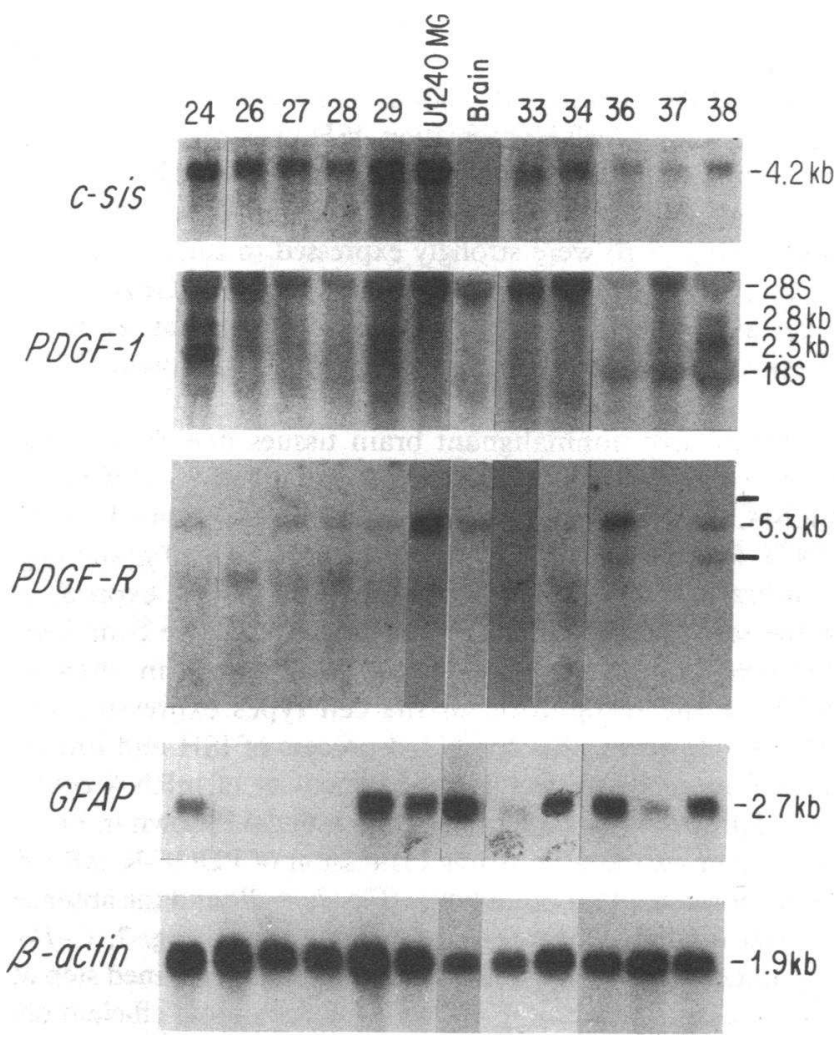

Figure 3. Northern blot analysis for c-sis/PDGF-2, PDGF-1, and PDGF-R(B) genes in primary human astrocytomas. Notice the absence of c-sis/PDGF-2 transcripts in normal brain tissue.

The cDNA probes for the present studies included c-sis/PDGF-2 (32); PDGF-1 (A) (22); the sis/PDGF-2-specific PDGF-R (27); $\beta$-actin (33); and glial fibrillary acidic protein (GFAP) (34).

In situ hybridization (ISH). Fresh tumor tissue was fixed immediately after excision in ice-cold $4 \%$ paraformaldehyde for $2 \mathrm{~h}$ and then was allowed to sink in $30 \%$ sucrose PBS overnight at $4^{\circ} \mathrm{C}$ to decrease freezing artifacts. In situ hybridization utilizing ${ }^{35} \mathrm{~S}$-labeled, cRNA probes for c-sis and PDGF-receptor was performed on 8- $\mu \mathrm{m}$ frozen sections according to the method of Hofler et al. (35). In some sections in situ hybridization was followed by immunohistochemistry for GFAP (Dako Corp., Copenhagen, Denmark).

The specificity of the probes for in situ hybridization was controlled by Northern blot analysis and by hybridization of serial sections with noncomplementary RNA probes.

Immunocytochemistry. Tissues were prepared as described for ISH. The tissue sections were hydrated in PBS, bleached with $0.3 \% \mathrm{H}_{2} \mathrm{O}_{2}$ in methanol, and reacted with the appropriate antibody using the Vectastain ABC Kit (Vector Laboratories, Burlingame, CA). The tissues were then counterstained with hematoxylin, dehydrated, cleared, and mounted. The specificity of the immunostaining was tested by replacing the primary antibody with preimmune sera, which should lead to negative results. The following specific antisera were used in these studies: polyclonal antisera against recombinant c-sis/PDGF-2 homodimer specific for the human PDGF heterodimer and PDGF-2 homodimer but not the PDGF-1 homodimer (Institute of Molecular Biology, Boston); PDGF-R antiserum raised against the synthetic polypeptide residue 958-980 of the cDNA sequence of Yarden et al. (kinase region) (27). This region of the PDGF-R has no homology to other known receptors.

\section{Results}

The results of gene expression by the primary astrocytomas are shown in Figs. 1-3. RNA was extracted from 34 individual primary human astrocytomas and was subjected to Northern blot analysis, along with control RNA extracted from U1240MG human astrocytoma cell line and from normal human brain. The U1240MG astrocytoma cell line has been shown previously to express the PDGF and PDGF-R genes. To determine if the amount of RNA applied in each lane was equivalent, the filters were rehybridized with a labeled $\beta$ actin probe, after washing, to remove the previous probe. Of the 34 samples analyzed, 4 were underloaded and they are not included in Figs. 1-3. Only RNA sample 14 was degraded. In addition, sequential hybridization to GFAP cDNA was performed. GFAP is a glial-specific structural protein and serves as a well-accepted marker for fully differentiated astrocytes (36).

Expression of the c-sis/PDGF-2 protooncogene. The c-sis oncogene was expressed in all astrocytoma samples examined (Figs. 1-3) including the four samples that were underloaded. The degree of expression varied widely among the individual tumors. The control normal brain tissue did not express the c-sis/PDGF-2 protooncogene. This is consistent with the in

Table I. Histopathologic Classification of the Astrocytoma Tumors Included in Figs. 1-3

\begin{tabular}{|c|c|c|}
\hline Lane No. & Classification & Grade* \\
\hline 1 & Glioblastoma & III \\
\hline 2 & Glioblastoma & III \\
\hline 3 & Glioblastoma & III \\
\hline 4 & Glioblastoma & III \\
\hline 5 & Glioblastoma & III \\
\hline 6 & Anaplastic astrocytoma & II/III \\
\hline 7 & Anaplastic astrocytoma & I-II/III \\
\hline 10 & Glioblastoma & III \\
\hline 11 & Anaplastic astrocytoma & II \\
\hline 12 & Glioblastoma & III \\
\hline 13 & Glioblastoma & III \\
\hline 14 & (Degraded sample) & \\
\hline 15 & Glioblastoma & III \\
\hline 16 & Glioblastoma & III \\
\hline 17 & Glioblastoma & III \\
\hline 18 & Anaplastic astrocytoma & II/III \\
\hline 19 & Glioblastoma & III \\
\hline 21 & Glioblastoma & III \\
\hline 22 & Anaplastic astrocytoma & II \\
\hline 23 & Glioblastoma & III \\
\hline 24 & Glioblastoma & III \\
\hline 26 & Glioblastoma & III \\
\hline 27 & Glioblastoma & III \\
\hline 28 & Glioblastoma & III \\
\hline 29 & Glioblastoma & III \\
\hline 33 & Anaplastic astrocytoma & II \\
\hline 34 & Glioblastoma & III \\
\hline 36 & Glioblastoma & III \\
\hline 37 & Anaplastic astrocytoma & II/III \\
\hline 38 & Glioblastoma & III \\
\hline
\end{tabular}

* Graded according to the World Health Organization standards (Zulch, K. J. Histological typing of tumors of the central nervous system. International histological classification of tumors. No. 21. Geneva: World Health Organization, 1979). 
situ hybridization data described below that demonstrated a lack of expression of c-sis mRNA in the five specimens of nonmalignant human brain.

Expression of the PDGF-1 (A) gene. The PDGF-1 gene was expressed in 27 of 29 astrocytomas shown in Figs. 1-3. The degree of expression varied among the samples tested, and it was significantly weaker than the c-sis gene expression. This necessitated a longer exposure time (10 d) during autoradiography causing significant background expression of $18 \mathrm{~S}$ and 28S RNA. In contrast, the exposure time for c-sis was only 24 h. The PDGF-1 gene expression appears to be independent of the expression of the c-sis protooncogene.

Expression of the PDGF-R gene. The PDGF-R gene was expressed by all astrocytomas tested. The intensity of the expression differed significantly among the individual astrocytoma tissues examined. An important finding was the identification of novel PDGF-R transcripts of $\sim 3.2$ and $7.2 \mathrm{~kb}$, compared to the expected $5.3 \mathrm{~kb}$ transcript. These novel transcripts were not present in RNA derived from the control U1240MG cell lines (Fig. 3) or in RNA derived from primary human meningiomas (36a). Studies in progress indicate that the 3.2-kb receptor transcript which is predominant in lane 21 (Fig. 2) retains the receptor kinase region as judged by immunostaining of the tissue with antisera raised against the synthetic peptide to the kinase region of the receptor.

Localization of PDGF and PDGF-R $m R N A$ 's in astrocytoma and in nonmalignant brain tissues. Northern blot analysis demonstrated the co-expression of the PDGF and PDGF-R genes by primary human astrocytoma tissue. Localization of the cells expressing these genes in the primary tissue was exam- ined by in situ hybridization. As shown in Fig. 4, ISH demonstrated the expression of c-sis/PDGF-2 mRNA in tumor cells and in capillary endothelial cells as identified by light microscopy. For further cell identification, ISH in astrocytoma tissue was combined with immunostaining using antibody to GFAP. As shown in Fig. 5, c-sis mRNA (Fig. $5 A$ ) and PDGF-R mRNA (Fig. $5 B$ ) were strongly expressed in tumor cells, including dividing cells that were stained weakly by GFAP. This is consistent with previous findings indicating that the more primitive and anaplastic cells in astrocytomas express GFAP weakly, or not at all $(37,38)$.

ISH in five nonmalignant brain tissues demonstrated a strong expression of PDGF-R mRNA but not of c-sis/PDGF-2 mRNA. Fig. 6 presents an example of the expression of PDGF-R mRNA (Fig. 6, $A-B$ ) in the astrocytes of nonmalignant brain tissue, and the absence of c-sis mRNA expression in the same tissue (Fig. 6, $C-D$ ). In this study we combined ISH with immunostaining with GFAP antibody in order to facilitate the recognition of the cell types expressing the mRNA. However, this combined process of ISH and immunostaining tends to decrease the sensitivity of mRNA detection. This becomes evident from the ISH data shown in Fig. 7 which demonstrate the strong expression of PDGF-R mRNA in the nonmalignant brain tissue (Fig. 7, $A-B$ ) and the absence of c-sis mRNA expression in the same tissue (Fig. 7, $C-D$ ). The data shown in Fig. 7 did not include the combined step of immunostaining with GFAP, allowing for a more efficient detection of mRNA. The specificity of the ISH data was controlled with ISH of serial sections using noncomplementary "sense" RNA probes. These control data with the sense probes did not demonstrate significant mRNA expression. These

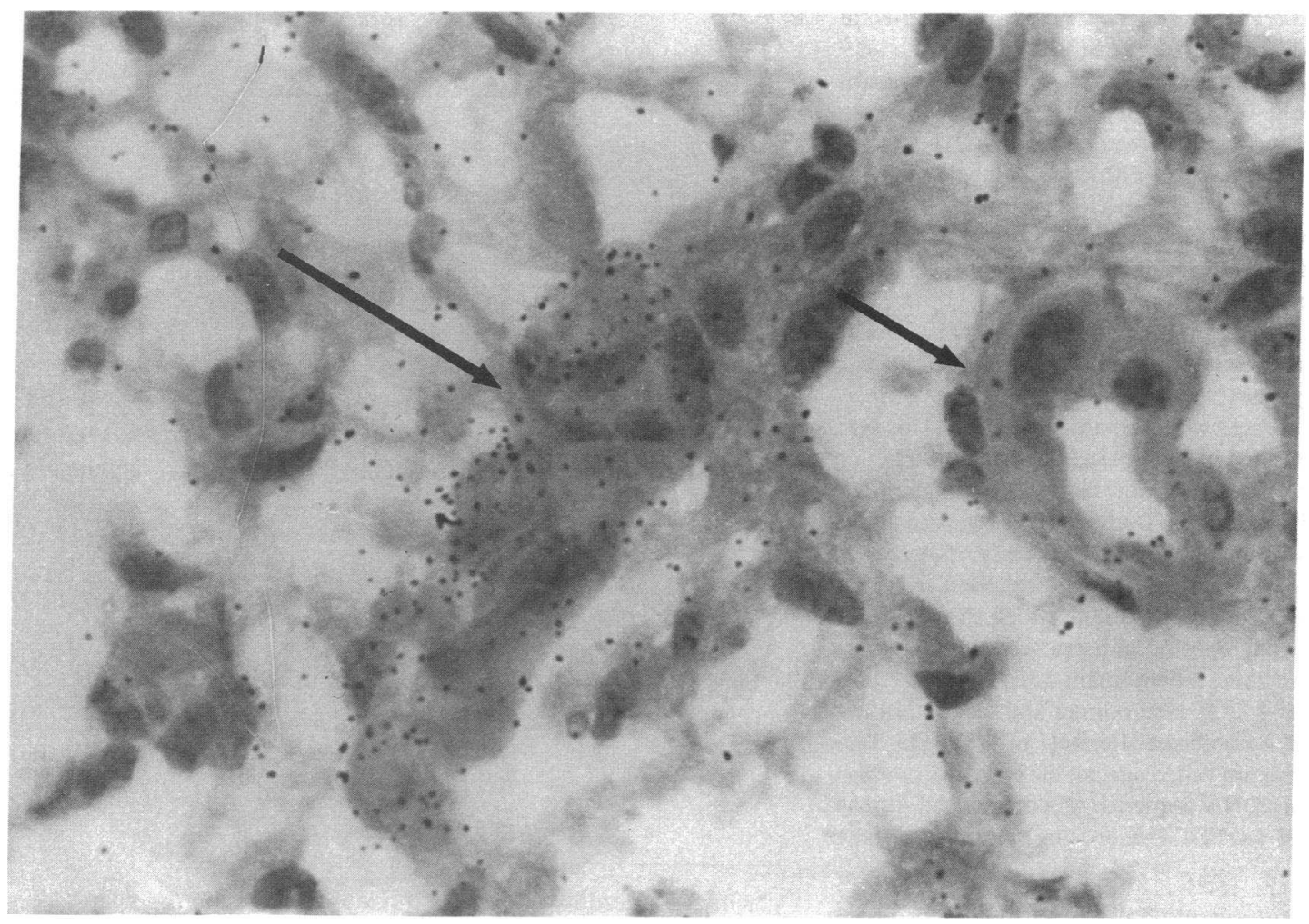

Figure 4. In situ hybridization for c-sis in a primary human astrocytoma. Focal hybridization of ${ }^{35}$ S-labeled, cRNA probe is observed over a cluster of tumor cells (long arrow). Adjacent endothelial cells (short arrow) show much less hybridization $(\times 1,000)$. 

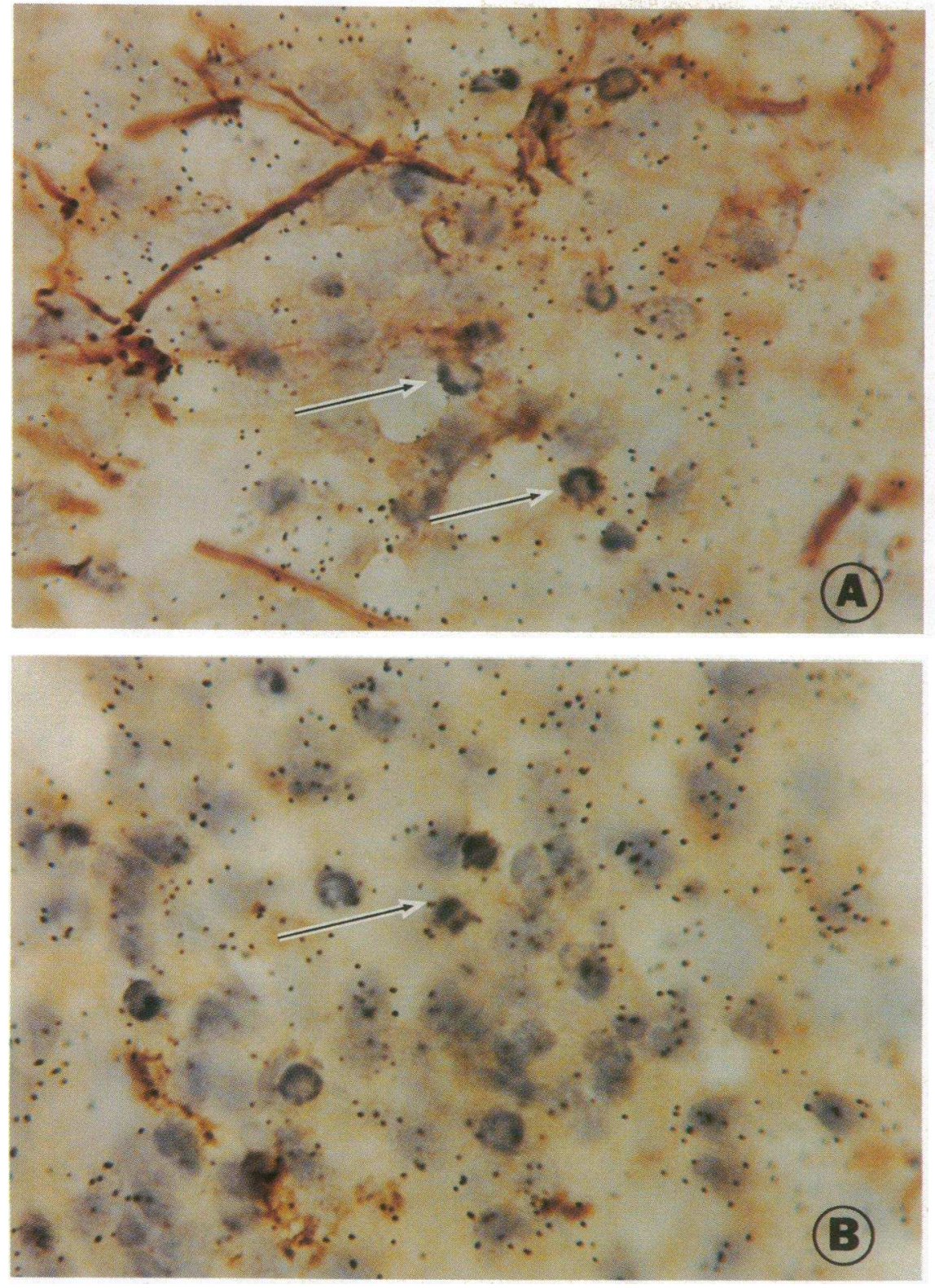

Figure 5. Localization of c-sis and PDGF$R(B)$ mRNA in a primary human astrocytoma by in situ hybridization. Paraformaldehydefixed frozen sections were hybridized with ${ }^{35} \mathrm{~S}$ labeled, cRNA probes for c-sis $(A)$ or PDGFreceptor $(B)$ followed by immunohistochemical staining for GFAP. Hybridization of both the c-sis and PDGF-R probes is seen over tumor cells, some of which show mitotic figures (arrows). Processes from adjacent cells demonstrate strong staining for GFAP while faint GFAP reactivity is present in tumor cells $(\times 1,000)$. findings are consistent with those obtained by Northern blot analysis which demonstrated the presence of PDGF-R but not of c-sis transcripts in a normal brain tissue (Fig. 3).

ISH failed to localize the PDGF-1 mRNA in astrocytoma tissue due to a weak expression of this gene. This is consistent with the Northern blot analysis data, which indicated a weak expression of the PDGF-1 gene in astrocytoma tissue.

Expression of PDGF-like and PDGF-R-like proteins. Immunocytochemistry of astrocytoma tissue demonstrated the expression of both PDGF-like and PDGF-R-like proteins, using specific anti-PDGF-2 homodimer, and anti-receptor antisera (Fig. 8, $A$ and $C$ ). The specificity of these findings was checked by preincubating the antisera with excess recombinant PDGF-2 homodimer (50 ng) or the synthetic receptor peptide (100 ng), which provided negative results (Fig. 8, $B$ and $D$ ). Control, nonmalignant brain tissue expressed only PDGF-R-like but not PDGF-like proteins (data not shown).

\section{Discussion}

The present findings have demonstrated the coexpression of the two PDGF genes together with the PDGF-R gene by a large number of primary human astrocytomas. All of the 29 primary tumors included in our data expressed both the c-sis/ PDGF-2 protooncogene and the PDGF-R gene, and 27 of the tumors also expressed the PDGF-1 gene. In situ hybridization demonstrated a strong expression of c-sis mRNA in tumor cells. Capillary endothelial cells in astrocytomas also expressed c-sis mRNA. This is not surprising since neovascularization is associated with astrocytomas and expression of the c-sis protooncogene by endothelial cells has been reported previously $(39,40)$. A strong expression of PDGF-R mRNA was also shown in the tumor cells. The expression of both c-sis and PDGF-R mRNA's was accompanied by the expression of their respective protein products as determined by immunohisto- 

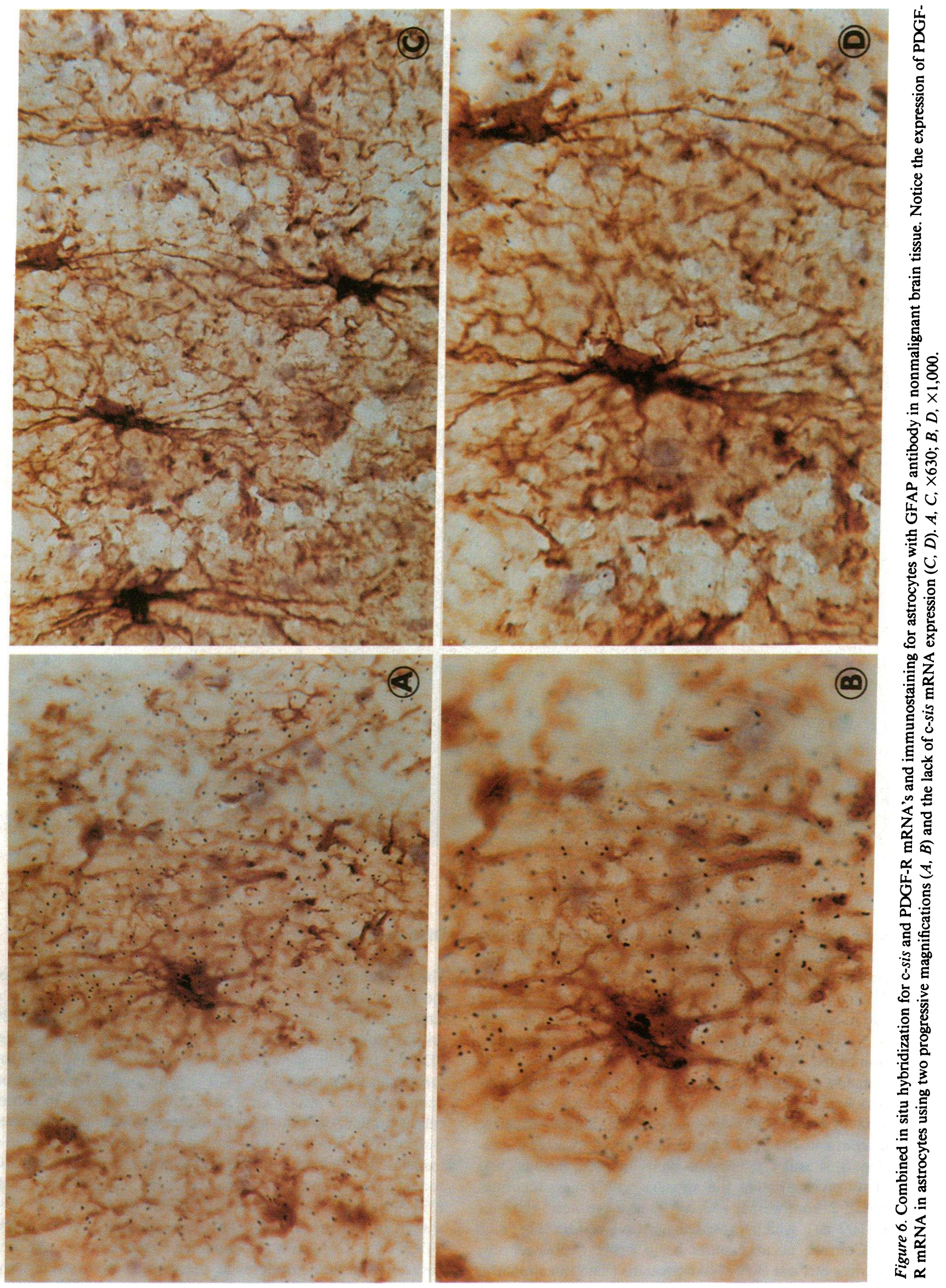

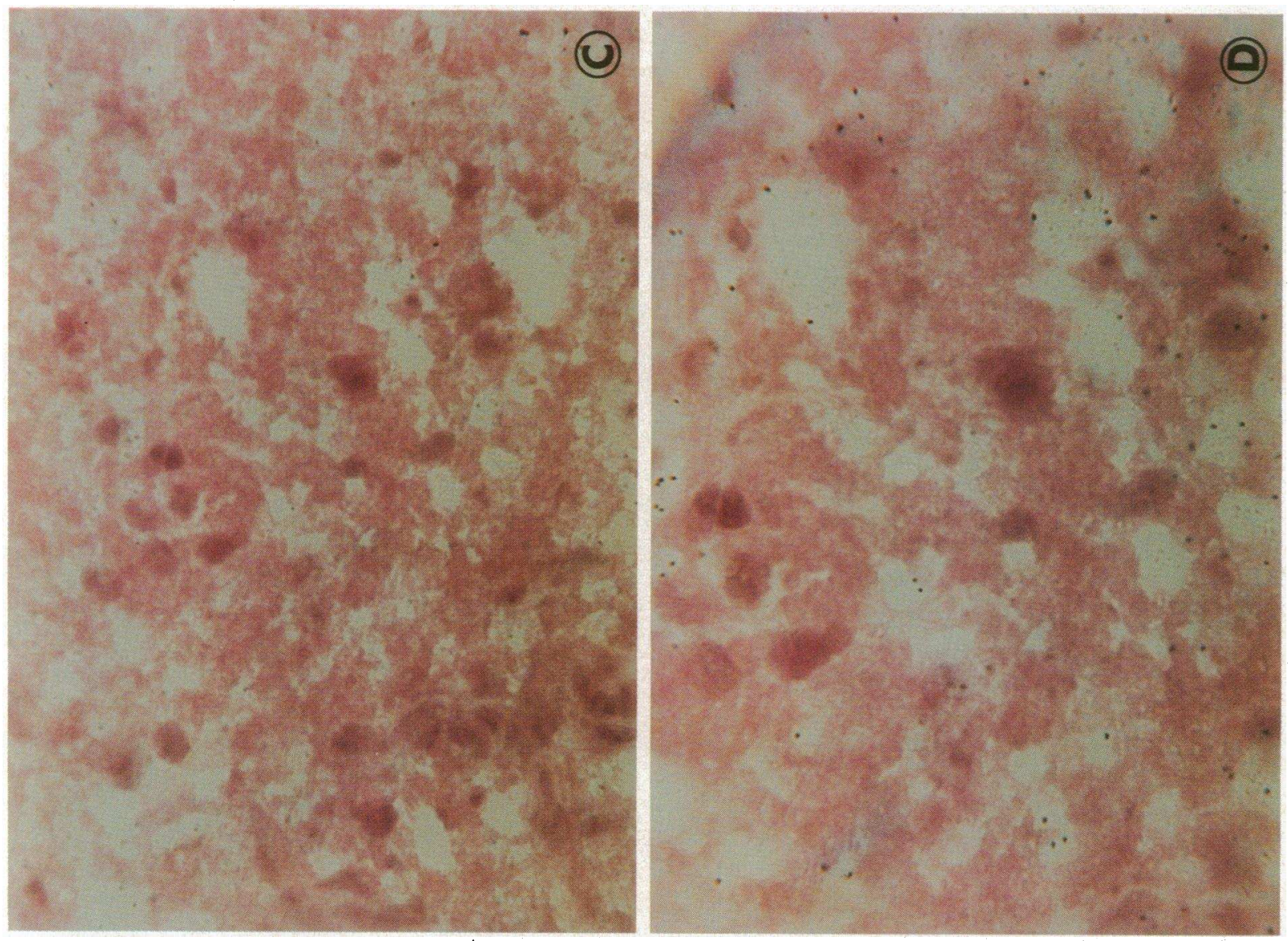

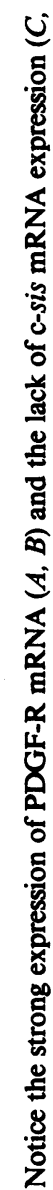
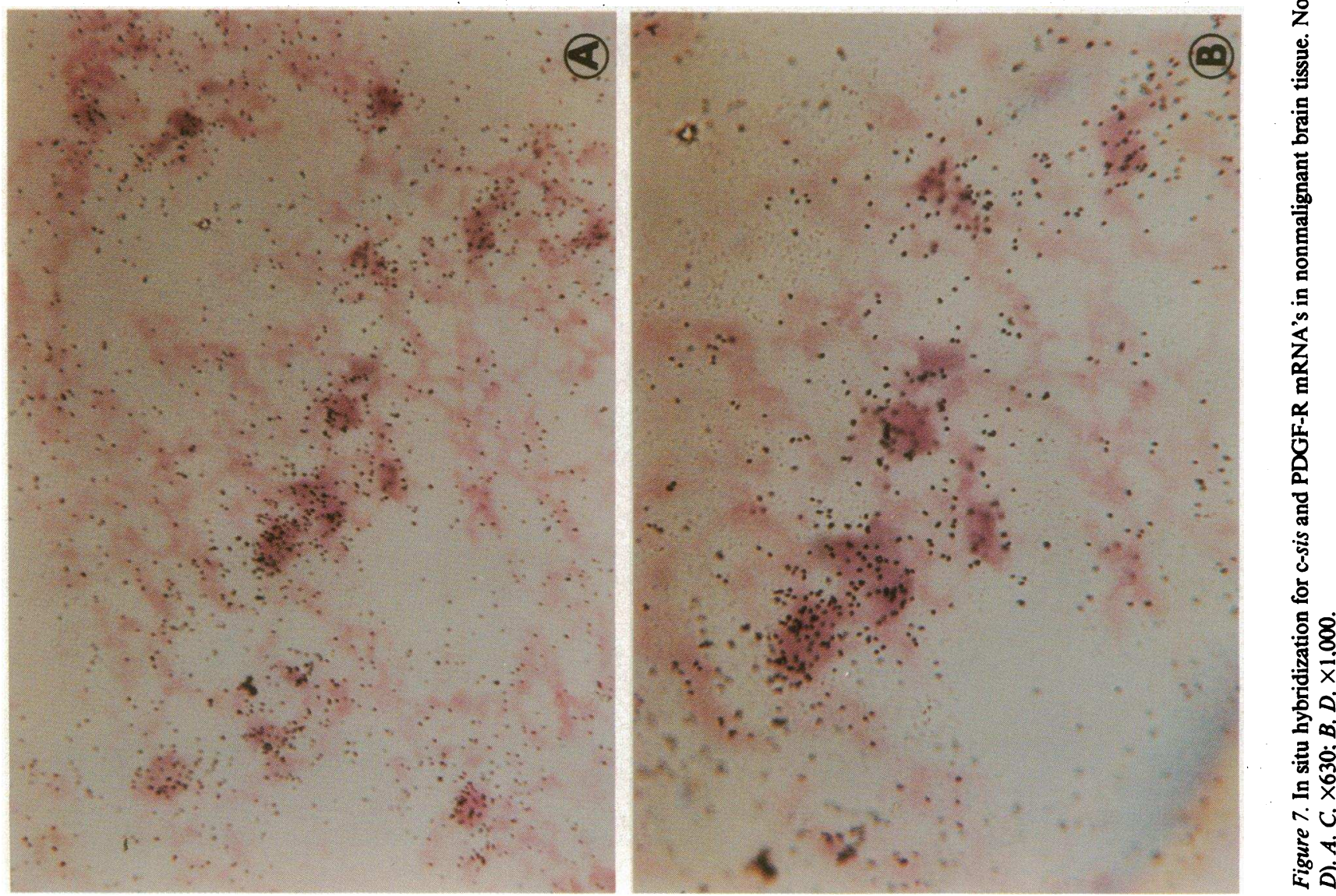

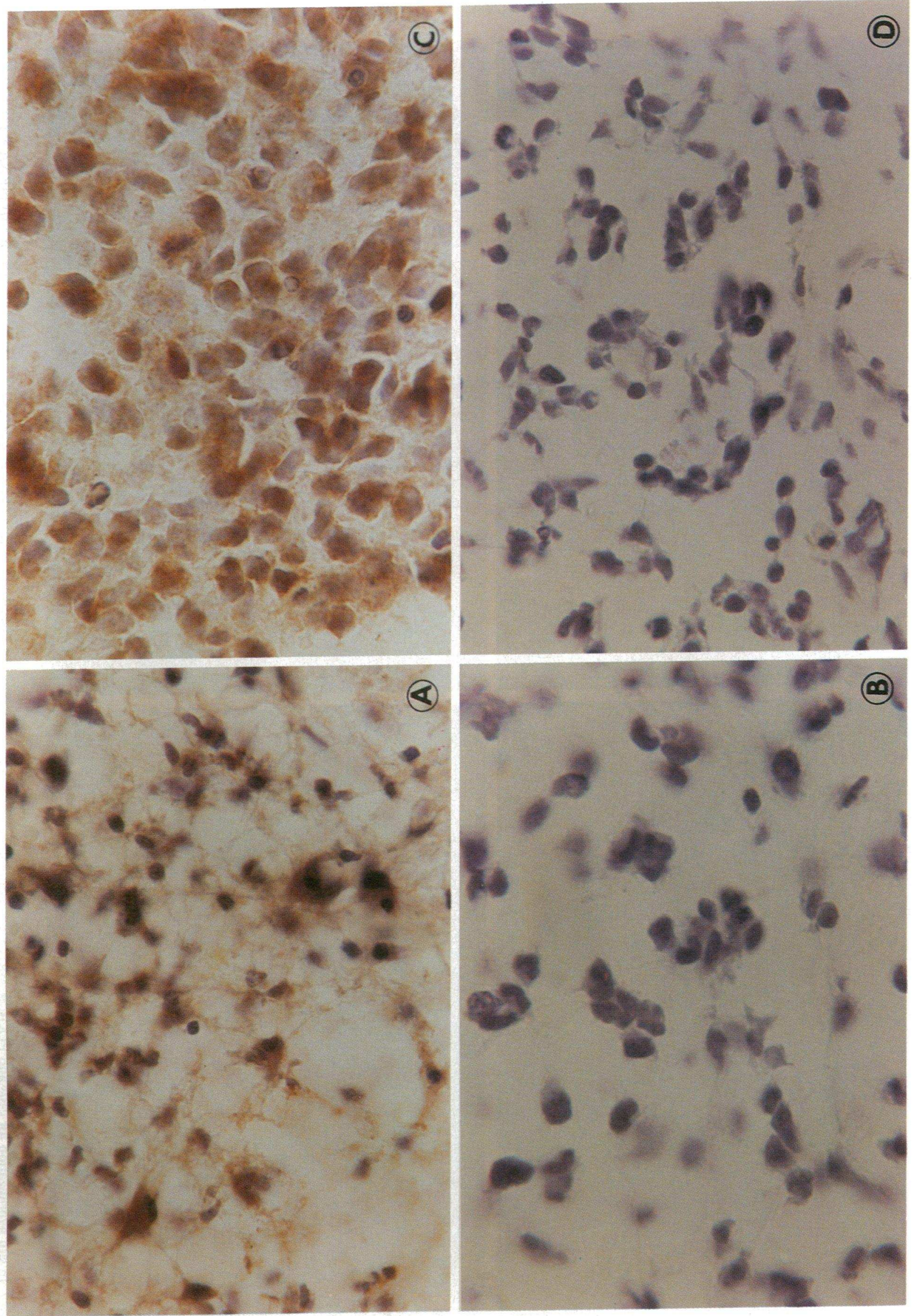
chemistry. These findings suggest the presence of an autocrine mechanism that involves the coexpression of a potent mitogenic growth factor and its receptor. This coexpression may contribute to the unregulated growth of the malignant astrocytes. A link between sis/PDGF-2 expression and transformation has been suggested to explain the ability of the SSV to induce transformation in cell culture $(16,17,41)$, and gliomas in monkeys (26). Neoplastic transformation induced by the $\mathrm{v}$-sis oncogene was attributed to the constitutive expression of a PDGF-like mitogen by the transformed cells causing sustained, unregulated cell proliferation (41).

Nonmalignant brain tissue expressed only the PDGF-R and PDGF-1 genes, but not the c-sis/PDGF-2 protooncogene. Northern blot analysis of a single specimen and in situ hybridization of five specimens failed to recognize expression of c-sis mRNA in normal cerebral cortex. Similarly, antisera against the PDGF-2 homodimer also failed to detect the presence of PDGF-like proteins in brain tissue. These data may indicate that the c-sis mRNA is inappropriately expressed in astrocytoma tissue. This is consistent with in vitro findings that demonstrated the inappropriate expression of c-sis mRNA in established cell lines derived from human tumors such as glioblastoma, fibrosarcoma, and osteosarcoma $(13,14,42)$. The normal counterparts of these malignant cells are targets to PDGF action, expressing cell surface PDGF-R but not the two PDGF genes. Recent studies in rat optic nerve have suggested that PDGF is crucial for controlling the differentiation of embryonic glial progenitor cells and therefore for the control of myelination in the developing central nervous system (43).

The PDGF-R gene was expressed by all astrocytoma samples studied together with normal cerebral cortical controls. Northern blot analysis demonstrated the presence of novel PDGF-R transcripts in several astrocytoma specimens. These novel transcripts were both smaller $(\sim 3.2 \mathrm{~kb})$ and larger $(\sim 7.2 \mathrm{~kb})$ than the normal $5.3 \mathrm{~kb}$ PDGF-R transcript. These novel PDGF-R transcripts were not found in RNA derived from primary human meningiomas (36a), or from normal and malignant cell lines expressing the PDGF-R gene. The significance of these transcripts is not known. It is possible that they are associated with certain subclasses of astrocytomas. The PDGF-1 gene was shown to be weakly expressed and thus the unequivocal identification of its cells of origin by ISH was not conclusive. The functional role of the PDGF-1 gene and its distinct receptor gene in primary astrocytomas remains at present unknown.

The present data suggest the presence of an autocrine mechanism in primary human astrocytomas that may contribute to the growth and maintenance of these tumors. At the same time our data indicate the possibility that the detection of the c-sis/PDGF-2 mRNA in astrocytomas may serve in the early diagnosis of these tumors. The ability to detect expression of c-sis mRNA by in situ hybridization, and its protein product by immunostaining may provide a powerful tool for early detection of the expression of this protooncogene in small amounts of tissue obtained in stereotactic biopsies.

\section{Acknowledgments}

The authors wish to acknowledge generous donations of astrocytoma tissue by the following neurosurgeons: Dr. Julian Wu, New England Medical Center, Boston, MA; Dr. Donald Wright, National Institutes of Health; Dr. Mark Erasmus, Albuquerque, NM; Dr. David Dunn, Milwaukee, WI. We express our thanks to Mrs. Amal Ghaly for the preparation of this manuscript.

These studies were supported by National Institutes of Health grants CA-30101, HL-29583 (Dr. Antoniades), and The Council for Tobacco Research, U.S.A., Inc. (Dr. Antoniades).

\section{References}

1. Rubenstein, L. J. 1972. Atlas of tumor pathology. Second series. Fascicle 6. Tumors of the central nervous system. Armed Forces Institute of Pathology, Washington, DC. 10-11.

2. Bailey, P., and H. Cushing. 1926. A classification of the tumors of the glioma group on a histogenic basis with a correlated study of prognosis. J. B. Lippincott Co., Philadelphia.

3. Kernohan, J. W., R. F. Mabon, H. J. Svien, and A. W. Adson. 1949. A simplified classification of the gliomas. Proc. Staff Meet. Mayo Clin. 24:71-75.

4. Burger, P. C., and F. S. Vogel. 1982. Surgical pathology of the nervous system and its coverings. John Wiley and Sons, New York. 226-242.

5. Russell, D. S., and L. J. Rubinstein. 1971. Pathology of Tumors of the Nervous System. Williams and Wilkins Co., Baltimore. 168-170.

6. Seeger, R. C., G. M. Brodeur, H. Sather, A. Dalton, S. E. Siegel, K. Y. Wong, and D. Hammond. 1985. Association of multiple copies of the $\mathrm{N}$-myc oncogene with rapid progression of neuroblastomas. $N$. Engl. J. Med. 313:1111-1116.

7. Johnson, B. E., D. C. Ihde, R. W. Makuch, A. F. Gazdar, D. N. Carney, H. Oie, E. Russell, M. M. Nau, and J. E. Minna. 1987. myc family oncogene amplification in tumor cell lines established from small cell lung cancer patients and its relationship to clinical status and course. J. Clin. Invest. 79:1629-1634.

8. Slamon, D. J., W. Godolphin, L. A. Jones, J. A. Holt, S. G. Wong, D. E. Keith, W. J. Levin, S. G. Stuart, J. Udove, A. Ullrich, and M. F. Press. 1989. Studies of the HER-2/neu proto-oncogene in human breast and ovarian cancer. Science (Wash. DC.). 244:707-712.

9. Van de Vijver, M. J., J. L. Peterse, W. J. Mooi, P. Wisman, J. Lomans, O. Dalesio, and R. Nusse. 1988. Neu-protein overexpression in breast cancer. Association with comedo/type ductal carcinoma in situ and limited prognostic value in stage II breast cancer. $N$. Engl. J. Med. 319:1239-1245.

10. Liberman, T. A., H. R. Nusbaum, N. Razon, R. Kris, I. Lax, H. Soreq, N. Whittle, M. D. Waterfield, A. Ullrich, and J. Schlessinger. 1985. Amplification, enhanced expression, and possible rearrangement of EGF receptor gene in primary human brain tumors of glial origin. Nature (Lond.). 313:144-147.

11. Kinzler, K. W., S. H. Bigner, D. D. Bigner, J. M. Trent, M. L. Law, S. J. O'Brien, A. J. Wong, and B. Vogelstein. 1987. Identification of an amplified, highly expressed gene in a human glioma. Science (Wash. DC). 236:70-73.

12. Bigner, S. H., P. C. Burger, A. J. Wong, and M. H. Werner. 1988. Gene amplification in malignant human gliomas: clinical and histopathologic aspects. J. Neuropathol. Exp. Neurol. 47:191-205.

Figure 8. Immunocytochemistry for c-sis/PDGF-2-like and PDGF receptorlike proteins in a primary human astrocytoma tumor. Staining for PDGF-like $(A)$ and PDGF-R-like $(C)$ proteins is observed using antisera against recombinant PDGF-2 homodimer $(A)$ and PDGF-R $(C)$. Staining with antisera preincubated with excess PDGF-2 homodimer $(50 \mathrm{ng})(B)$ or PDGF-R synthetic peptide $(100 \mathrm{ng})(D)$ produced negative results $(\times 630)$. 
13. Pantazis, P., P. A. Pelicci, R. Dalla-Favera, and H. N. Antoniades. 1985. Synthesis and secretion of proteins resembling platelet-derived growth factor by human glioblastoma and fibrosarcoma cells in culture. Proc. Natl. Acad. Sci. USA. 82:2404-2408.

14. Nister, M., T. A. Libermann, C. Betsholtz, M. Peterson, L. Claeson-Welsch, C. H. Heldin, J. Schlessinger, and B. Westermark. 1988. Expression of messenger RNAs for platelet-derived growth factor and transforming growth factor- $\alpha$ and their receptors in human malignant glioma cell lines. Cancer Res. 48:3910-3918.

15. Antoniades, H. N., and M. W. Hunkapiller. 1983. Human platelet-derived growth factor (PDGF): Amino-terminal amino acid sequence. Science (Wash. DC). 220:963-965.

16. Doolittle, R. F., M. W. Hunkapiller, L. E. Hood, S. G. Devare, K. C. Robbins, S. A. Aaronson, and H. N. Antoniades. 1983. Simian sarcoma virus onc gene, $\mathrm{v}$-sis, is derived from the gene (or genes) encoding a platelet derived growth factor. Science (Wash. DC). 221:275-277.

17. Robbins, K. C., H. N. Antoniades, S. G. Devare, M. W. Hunkapiller, and S. A. Aaronson. 1983. Structural and immunological similarities between simian sarcoma virus gene product(s) and human platelet-derived growth factor. Nature (Lond.). 305:605-608.

18. Johnsson, A., C. H. Heldin, A. Wasteson, B. Westermark, T. F. Deuel, J. S. Huang, P. H. Seeburg, E. Gray, A. Ullrich, A. Scrace, G. Strooband, and M. D. Waterfield. 1984. The c-sis gene encodes a precursor of the B chain of platelet-derived growth factor. $E M B O$ (Eur. Mol. Biol. Organ) J. 3:921-928.

19. Antoniades, H. N., P. Pantazis, and A. J. Owen. 1987. Human platelet-derived growth factor and the sis/PDGF-2 gene. In Oncogenes, Genes, and Growth Factors. G. Guroff, editor. John Wiley and Sons, New York. 1-40.

20. Dalla-Favera, R., R. Gallo, C. Giallongo, and C. Croce. 1982. Chromosomal localization of the human homolog (c-sis) of the simian sarcoma virus onc gene. Science (Wash. DC). 218:686-688.

21. Swan, D. C., O. W. McBride, K. C. Robbins, D. A. Keithley, E. P. Reddy, and S. A. Aaronson. 1982. Chromosome mapping of the simian sarcoma virus onc gene analog in human cells. Proc. Natl. Acad. Sci. USA. 79:4691-4695.

22. Betsholtz, C., A. Johnsson, C. H. Heldin, and. 1986. cDNA sequence and chromosomal localization of human platelet-derived growth factor A-chain and its expression in tumor cell lines. Nature (Lond.). 320:695-699.

23. Rao, C. D., H. Igaraashi, I. M. Chin, K. C. Robbins, and S. A. Aaronson. 1986. Structure and sequence of the human c-sis platelet derived growth factor 2 (sis/PDGF2) transcriptional unit. Proc. Natl. Acad. Sci. USA. 83:2392-2396.

24. Hermansson, M., M. Nister, C. Betsholtz, C. H. Heldin, B. Westermark, and K. Funa. 1988. Endothelial cell hyperplasia in human glioblastoma: co-expression of mRNA for platelet-derived growth factor (PDGF)-B chain and PDGF receptor suggests autocrine growth stimulation. Proc. Natl. Acad. Sci. USA. 85:7748-7752.

25. Heldin, C.-H., B. Westermark, and A. Wasteson. 1981. Specific receptors for platelet-derived growth factor on cells derived from connective tissue and glia. Proc. Natl. Acad. Sci. USA. 78:3664-3668.

26. Deinhardt, F. 1980. Biology of primate retroviruses. In Viral Oncology. G. Klein, editor. Raven Press, New York. 357-398.

27. Yarden, Y., J. A. Escobedo, W.-J. Kuang, T. L. Yang-Feng, T. O. Daniel, P. M. Tremble, E. Y. Chen, H. E. Ando, R. N. Harkins, V. Francke, V. A. Fried, A. Ullrich, and L. T. Williams. 1986. Structure of the receptor for platelet-derived growth factor helps define a family of closely-related growth factor receptors. Nature (Lond.). 323:226-232

28. Gronwald, R. K., F. J. Grant, B. A. Haldeman, C. E. Hart, P. O'Hara, F. S. Hagen, R. Ross, and D. F. Bowen-Pope. 1988. Cloning and expression of a cDNA coding for the human platelet-derived growth factor receptor: Evidence for more than one receptor class. Proc. Natl. Acad. Sci. USA. 85:3435-3439.

29. Hart, C. E., J. W. Forstrom, J. D. Kelly, R. A. Seifert, R. A Smith, R. Ross, M. J. Murray, and D. F. Bowen-Pope. 1988. Two classes of PDGF receptor recognize different isoforms of PDGF. Science (Wash. DC). 240:1529-1531.

30. Heldin, C. H., G. Backstrom, A. Ostman, A. Hammacher, L. Rönnstrand, K. Rubin, M. Nister, and B. Westermark. 1989. Binding of different dimeric forms of PDGF to human fibroblasts: Evidence for two separate receptor types. EMBO (Eur. Mol. Biol. Organ.) J. 7:1387-1393.

31. Matsui, T., M. Heidaran, T. Miki, N. Popescu, W. LaRochelle, M. Kraus, J. Pierce, and S. Aaronson. 1989. Isolation of a novel receptor cDNA establishes the existence of two PDGF receptor genes. Science (Wash. DC). 243:800-804.

32. Collins, T., D. Ginsburg, J. M. Boss, S. H. Orkin, and J. S. Pober. 1985. Cultured human endothelial cells express platelet-derived growth factor B chain: cDNA cloning and structural analysis. Nature (Lond.). 316:748-750.

33. Ponte, P., S.-Y. Ng, J. Engel, P. Ganning, and L. Kedes. 1984. Evolutionary conservation in the untranslated regions of actin mRNAs: DNA sequence of a human beta-actin cDNA. Nucleic Acids Res. 12:1687-1696.

34. Lewis, S. A., J. M. Balcarek, V. Krek, M. Shelanski, and N. J. Cowan. 1984. Sequence of a cDNA clone encoding mouse glial fibrillary acidic protein: structure conservation of intermediate filaments. Proc. Natl. Acad. Sci. USA. 81:2743-2746.

35. Hofler, H., H. Childers, M. R. Monminy, R. M. Lechan, R. H. Goodman, and H. J. Wolfe. 1986. In situ hybridization methods for the detection of somatostatin mRNA in tissue sections using antisense RNA probes. Histochem. J. 18:597-604.

36. Eng, L. F., R. A. Shiurba. 1988. Glial fibrillary acidic protein: A review of structure, function, and clinical application. In Neuronal and Glial proteins. Structure, Function, and Clinical Application. P. J. Marangos, I. C. Campbell, R. M. Cohen, editors. Academic Press, Inc. 339-350.

36a. Maxwell, M., T. Galanopoulos, E. T. Hedley-Whyte, P. McL. Black, and H. N. Antoniades. 1990. Human menangiomas coexpress platelet-derived growth factor (PDG7) and PDG7 receptor genes and their protein products. Int. J. Cancer. 46:In press.

37. DeArmond, S. J., L. F. Eng, and L. J. Rubinstein. 1980. The application of glial fibrillary acidic (GFA) protein immunohistochemistry in neurooncology: A progress report. Pathol. Res. Pract. 168:374-394.

38. Eng, L. F., and L. J. Rubinstein. 1978. Contribution of immunohistochemistry to diagnostic problems to human cerebral tumors. J. Histochem. Cytochem. 7:513-522.

39. Barrett, T. B., C. M. Gajdusek, S. M. Schwartz, J. K. Schwartz, and E. P. Benditt. 1984. Expression of the sis gene by endothelial cells in culture and in vivo. Proc. Natl. Acad. Sci. USA. 81:6772-6774.

40. Sitaras, N. M., E. Sariban, P. Pantazis, B. Zetter, and H. N. Antoniades. 1987. Human iliac artery endothelial cells express both genes encoding the chains of platelet-derived growth factor (PDGF) and synthesize PDGF-like mitogen. J. Cell Physiol. 132:376-380.

41. Antoniades, H. N. 1984. Platelet-derived growth factor and malignant transformation. Biochem. Pharmacol. 33:2823-2828.

42. Graves, D. T., A. J. Owen III, R. L. Barth, P. Tempst, A. Winoto, L. Fors, L. E. Hood, and H. N. Antoniades. 1984. Detection of c-sis transcripts and synthesis of platelet-derived growth factor (PDGF)-like proteins by human osteosarcoma cell. Science (Wash. DC). 226:972-974.

43. Richardson, W. D., N. Pringle, M. J. Mosley, B. Westermark, and M. Dubois-Dalcq. 1988. A role for platelet-derived growth factor in normal gliogenesis in the central nervous system. Cell. 53:309-319. 